\title{
Maternal Thyroid Function and Placental Hemodynamics
}

\author{
Ahmed R.G. \\ Division of Anatomy and Embryology, Zoology Department, Faculty of Science, Beni-Suef University, Beni- \\ Suef, Egypt
}

*Corresponding Author: Ahmed R.G, Division of Anatomy and Embryology, Zoology Department, Faculty of Science, Beni-Suef University, Beni-Suef,Egypt. Email: ahmedragab08@ gmail.com

\section{LETTER TO EDITOR}

The concentrations of thyroid hormones (THs) are necessary for the normal development(Elbakry et al., 2010; Ahmed, 2011, 2012a,b, 2013, 2014, 2015a-c, 2016a-d, 2017a-u \& 2018a-c; Ahmed et al., 2010, 2013a,b, 2014, 2015a,b \& 2018a,b; Ahmed and Incerpi, 2013; Van Hercket al., 2013; Ahmed andEl-Gareib, 2014,Incerpi et al., 2014; Candelotti et al., 2015; De Vito et al., 2015; El-Ghareeb et al., 2016; Ahmed and ElGareib, 2017) in particular the placentation (Barber et al., 2005; Krassas et al., 2010; Loubiere et al., 2010; Aghajanova et al., 2011; Patel et al., 2011; Barjaktarovic et al., 2017). On account of the normal placentation (interstitial invasion of fetal trophoblast cells into maternal decidua and endovascular trophoblast (EVT) invasion into maternal spiral arteries, Cartwright et al., 2010) is vital for maintaining the gestation and for the optimal fetal development; supply nutrients, exchange gases and eliminate the metabolic waste products, any disorders in the placental functions can cause several pregnancy complications such as the preeclampsia, premature delivery, and fetal growth restriction (Carter, 2012; Guttmacher et al., 2014; Fowden et al., 2015). These conditions may impair the fetal blood supply, deteriorate the placental hemodynamics and cause maternal and perinatal mortality and morbidity (Kovo et al., 2011; Bilano et al., 2014; Odibo et al., 2014; Vinnars et al., 2015; Barjaktarovic et al., 2017). THs can regulate the trophoblast proliferation, motility and EVT invasion by initiating the secretion of several growth factors (epidermal growth factor (EGF), and vascular endothelial growth factor-A (VEGF-A)), cytokines (tumor necrosis factor alpha (TNF- $\alpha$ ), and interleukin 10 (IL-10)), and angiogenesis of maternofetal placental vessels such as angiopoietin 2 (Ang-2) and angiogenin
(Matsuo et al., 1993; Oki et al., 2004; Barber et al., 2005; Vasilopoulou et al., 2014). These processes can be mediated by the normal expression of thyroid receptors (TRs; $\alpha$ and $\beta$ ) and the normal activities of thyroid transporters (THTs) in the trophoblast cells (Barber et al., 2005; Loubiere et al., 2010; Aghajanova et al., 2011; Patel et al., 2011). On the other hand, impair the normal placentation in early pregnancy (Cartwright et al., 2010) due to hyperthyroidism could cause fetal growth restriction (Medici et al., 2013; Haddow et al., 2014) and preeclampsia (Aggarawal et al., 2014; Medici et al., 2014). In addition, abnormal placentation in early pregnancy (Cartwright et al., 2010) due to hypothyroidism could cause premature delivery (Korevaar et al., 2013; Sheehan et al., 2015). From the clinical data, there are association between the thyroid disorders and placental dysfunction, and pregnancy complications (Korevaar et al., 2013; Medici et al., 2013, 2014; Odibo et al., 2014).

From the aforementioned clarifications and the current opinion, it can be inferred that the early normal activities of the maternal thyroid gland may be a regulator of the normal placentation. In addition, maternal thyroid dysfunctions (hyperthyroidism or hypothyroidism) can impair the placental growth factors, cytokines, and blood supply. The placental dysfunction may increase the risk of preeclampsia, fetal growth restriction and mortality. Thus, treatment of thyroid disorders before or during the gestation may decrease the risk of pregnancy complications. Additional investigations are necessary not only to examine the biological and molecular mechanisms between the thyroid dysfunction and placental disorders, preeclampsia and premature delivery but also to compare the data with the clinical studies. 


\section{REFERENCES}

[1] Aggarawal, N., Suri, V., Singla, R., Chopra, S., Sikka, P., Shah, V.N., Bhansali, A., 2014. Pregnancy outcome in hyperthyroidism: a case control study. GynecolObstet Invest 77, 94-99.

[2] Aghajanova, L., Stavreus-Evers, A., Lindeberg, M., Landgren, B.M., Sparre, L.S., Hovatta, O., 2011. Thyroid-stimulating hormone receptor and thyroid hormone receptors are involved in human endometrial physiology. FertilSteril 95, 230-237.

[3] Ahmed, O.M., Abd El-Tawab, S.M., Ahmed, R.G., 2010. Effects of experimentally induced maternal hypothyroidism and hyperthyroidism on the development of rat offspring: I- The development of the thyroid hormonesneurotransmitters and adenosinergic system interactions. Int. J. Dev. Neurosci. 28, 437-454.

[4] Ahmed, O.M., Abd El-Tawab, S.M.,Ahmed, R.G., 2010. Effects of experimentally induced maternal hypothyroidism and hyperthyroidism on the development of rat offspring: I- The development of the thyroid hormonesneurotransmitters and adenosinergic system interactions.Int. J. Dev. Neurosci. 28, 437-454.

[5] Ahmed, O.M., Ahmed, R.G., 2012. Hypothyroidism. In A New Look At Hypothyroidism. Dr. D. Springer (Ed.), ISBN:978-953-51-0020-1), In Tech Open Access Publisher, Chapter 1, pp. 1-20.

[6] Ahmed, O.M., Ahmed, R.G., El-Gareib, A.W., El-Bakry, A.M., Abd El-Tawaba, S.M., 2012. Effects of experimentally induced maternal hypothyroidism and hyperthyroidism on the development of rat offspring: II-The developmental pattern of neurons in relation to oxidative stress and antioxidant defense system. Int. J. Dev. Neurosci. 30, 517-537.

[7] Ahmed, O.M., El-Gareib, A.W., El-bakry, A.M., Abd El-Tawab, S.M., Ahmed, R.G., 2008. Thyroid hormones states and brain development interactions. Int. J. Dev. Neurosci. 26(2), 147-209. Review.

[8] Ahmed, R.G., 2011. Perinatal 2, 3, 7, 8tetrachlorodibenzo-p-dioxin exposure alters developmental neuroendocrine system. Food Chem. Toxicology, 49, 1276-1284.

[9] Ahmed, R.G., 2012a. Maternal-newborn thyroid dysfunction.In the Developmental Neuroendocrinology, pp. 1-369. Ed R.G. Ahmed. Germany: LAP LAMBERT Academic Publishing $\mathrm{GmbH} \& \mathrm{Co} \mathrm{KG}$.

[10] Ahmed, R.G., 2012b. Maternal-fetal thyroid interactions, Thyroid Hormone, Dr. N.K. Agrawal (Ed.), ISBN: 978-953-51-0678-4, In Tech Open Access Publisher, Chapter 5, pp. 125-156.

[11] Ahmed, R.G., 2013. Early weaning PCB 95 exposure alters the neonatal endocrine system: thyroid adipokine dysfunction. J. Endocrinol. 219 (3), 205-215.

[12] Ahmed, R.G., 2014. Editorial: Do PCBs modify the thyroid-adipokine axis during development? Annals Thyroid Res. 1(1), 11-12.

[13] Ahmed, R.G., 2015a. Chapter 1: Hypothyroidism and brain development. In advances in hypothyroidism treatment.Avid Science Borsigstr.9, 10115 Berlin, Berlin, Germany. Avid Science Publications level 6, Melange Towers, Wing a, Hitec City, Hyderabad, Telangana, India. pp. 1-40.

[14] Ahmed, R.G., 2015b. Hypothyroidism and brain developmental players. Thyroid Research J. 8(2), 1-12.

[15] Ahmed, R.G., 2015c. Editorials and Commentary: Maternofetal thyroid action and brain development. J. of Advances in Biology; 7(1), 1207-1213.

[16] Ahmed, R.G., 2016a. Gestational dexamethasone alters fetal neuroendocrine axis. Toxicology Letters, 258, 46-54.

[17] Ahmed, R.G., 2016b. Neonatal polychlorinated biphenyls-induced endocrine dysfunction. Ann. Thyroid. Res. 2 (1), 34-35.

[18] Ahmed, R.G., 2016c. Maternal iodine deficiency and brain disorders. Endocrinol. Metab.Syndr.5, 223. http://dx.doi.org/ 10.4172/ 2161-1017.1000223.

[19] Ahmed, R.G., 2016d. Maternal bisphenol A alters fetal endocrine system: Thyroid adipokine dysfunction. Food Chem. Toxicology, 95, 168-174.

[20] Ahmed, R.G.,2017a. Developmental thyroid diseases and GABAergic dysfunction. EC Neurology 8.1, 02-04.

[21] Ahmed, R.G., 2017b. Hyperthyroidism and developmental dysfunction.Arch Med. 9, 4.

[22] Ahmed, R.G.,2017c. Anti-thyroid drugs may be at higher risk for perinatal thyroid disease. EC Pharmacology and Toxicology 4.4, 140-142.

[23] Ahmed, R.G.,2017d. Perinatal hypothyroidism and cytoskeleton dysfunction. Endocrinol MetabSyndr 6, 271. doi:10.4172/2161-1017. 1000271

[24] Ahmed, R.G.,2017e. Developmental thyroid diseases and monoaminergic dysfunction. Advances in Applied Science Research 8(3), 01-10.

[25] Ahmed, R.G.,2017f. Hypothyroidism and brain development.J. Anim Res Nutr.2(2), 13.

[26] Ahmed, R.G.,2017g. Antiepileptic drugs and developmental neuroendocrine dysfunction: Every why has A Wherefore.Arch Med 9(6), 2.

[27] Ahmed, R.G.,2017h. Gestational prooxidantantioxidant imbalance may be at higher risk for 
postpartum thyroid disease. Endocrinol MetabSyndr 6, 279. doi:10.4172/ 21611017.1000279.

[28] Ahmed, R.G.,2017i. Synergistic actions of thyroid-adipokines axis during development. EndocrinolMetabSyndr 6, 280. doi:10.4172/ 2161-1017.1000280.

[29] Ahmed, R.G.,2017j. Thyroid-insulin dysfunction during development. International Journal of Research Studies in Zoology 3(4), 73-75. DOI: http://dx.doi.org/10.20431/2454941X.0304010.

[30] Ahmed, R.G.,2017k. Developmental thyroid diseases and cholinergic imbalance. International Journal of Research Studies in Zoology 3(4), 70-72. DOI: http:// dx.doi.org/ 10.20431/2454-941X.0304009.

[31] Ahmed, R.G.,20171. Thyroid diseases and developmental adenosinergic imbalance.Int $\mathrm{J}$ ClinEndocrinol 1(2), 053-055.

[32] Ahmed, R.G.,2017m. Maternal anticancer drugs and fetal neuroendocrine dysfunction in experimental animals. EndocrinolMetabSyndr 6, 281.doi:10.4172/2161-1017.1000281.

[33] Ahmed, R.G.,2017n. Letter: Gestational dexamethasone may be at higher risk for thyroid disease developing peripartum. Open Journal Of Biomedical \& Life Sciences (Ojbili) 3(2), 01-06.

[34] Ahmed, R.G.,2017o.Deiodinases and developmental hypothyroidism. EC Nutrition 11.5, 183-185.

[35] Ahmed, R.G.,2017p.Maternofetal thyroid hormones and risk of diabetes. Int. J. of Res. Studies in Medical and Health Sciences 2(10), 18-21.

[36] Ahmed, R.G.,2017r.Association between hypothyroidism and renal dysfunctions. International Journal of Research Studies in Medical and Health Sciences 2(11), 1-4.

[37] Ahmed, R.G.,2017s.Maternal hypothyroidism and lung dysfunction. International Journal of Research Studies in Medical and Health Sciences 2(11), 8-11.

[38] Ahmed, R.G.,2017t.Endocrine disruptors; possible mechanisms for inducing developmental disorders.International journal of basic science in medicine (IJBSM) 2(4), xx$\mathrm{Xx}$. (in press)

[39] Ahmed, R.G.,2017u. Maternal thyroid hormones trajectories and neonatal behavioral disorders. ARC Journal of Diabetes and Endocrinology 3(2), 18-21.

[40] Ahmed, R.G.,2018a. Maternal hypothyroidism and neonatal testicular dysfunction. International Journal of Research Studies in Medical and Health Sciences 3(1), 8-12.

[41] Ahmed, R.G.,2018b. Maternal thyroid disorders and bone maldevelopment: Are you ready to take risks for your offspring? J Pharma PharmaSci (JPPS) in press. DOI: 10.29011/2574-7711. 100058.

[42] Ahmed, R.G.,2018c. Non-genomic actions of thyroid hormones during development. App ClinPharmacolToxicol: ACPT-108. DOI: 10.29011/ACPT-109. 100008.

[43] Ahmed, R.G., Abdel-Latif, M., Ahmed F., 2015a.Protective effects of GM-CSF in experimental neonatal hypothyroidism. International Immunopharmacology 29, 538543.

[44] Ahmed, R.G., Abdel-Latif, M., Mahdi, E., ElNesr, K., 2015b. Immune stimulation improves endocrine and neural fetal outcomes in a model of maternofetal thyrotoxicosis. Int. Immunopharmacol. 29, 714-721.

[45] Ahmed, R.G., Davis, P.J., Davis, F.B., De Vito, P., Farias, R.N., Luly, P., Pedersen, J.Z., Incerpi, S., 2013a. Nongenomic actions of thyroid hormones: from basic research to clinical applications. An update. Immunology, Endocrine \& Metabolic Agents in Medicinal Chemistry, 13(1), 46-59.

[46] Ahmed, R.G., El-Gareib, A.W. 2014.Lactating PTU exposure: I- Alters thyroid-neural axis in neonatal cerebellum. Eur. J. of Biol. and Medical Sci. Res. 2(1), 1-16.

[47] Ahmed, R.G., El-Gareib, A.W., 2017.Maternal carbamazepine alters fetal neuroendocrinecytokines axis. Toxicology 382, 59-66.

[48] Ahmed, R.G., El-Gareib, A.W., Incerpi, S., 2014. Lactating PTU exposure: II- Alters thyroid-axis and prooxidant-antioxidant balance in neonatal cerebellum. Int. Res. J. of Natural Sciences 2(1), 1-20.

[49] Ahmed, R.G.,El-Gareib, A.W., Shaker, H.M., 2018a.Gestational 3, $3^{\prime}, 4,4^{\prime}, 5$ penta chlorobiphenyl (PCB 126) exposure disrupts fetoplacental unit: Fetal thyroid-cytokines dysfunction. Life Sciences 192, 213-220.

[50] Ahmed, R.G., Incerpi, S., 2013. Gestational doxorubicin alters fetal thyroid-brain axis. Int. J. Devl. Neuroscience 31, 96-104.

[51] Ahmed, R.G., Incerpi, S., Ahmed, F., Gaber, A., 2013b. The developmental and physiological interactions between free radicals and antioxidant: Effect of environmental pollutants. J. of Natural Sci. Res. 3(13), 74-110.

[52] Ahmed, R.G.,Walaa G.H., Asmaa F.S., 2018b.Suppressive effects of neonatal bisphenol A on the neuroendocrine system.Toxicology and Industrial Health Journal (in press).

[53] Barber, K.J., Franklyn, J.A., McCabe, C.J., Khanim, F.L., Bulmer, J.N., Whitley, G.S., Kilby, M.D., 2005. The in vitro effects of triiodothyronine on epidermal growth factor- 
induced trophoblast function. J Clin Endocrinol Metab 90, 1655-1661.

[54] Barjaktarovic, M., Korevaar, T.I.M., Chaker, L., Jaddoe, V.W.V., de Rijke, Y.B., Visser, T.J., Steegers, E.A.P., Peeters, R.P., 2017. The association of maternal thyroid function with placental hemodynamics. Human Reproduction $1-9$.

[55] Bilano, V.L., Ota, E., Ganchimeg, T., Mori, R., Souza, J.P., 2014. Risk factors of preeclampsia/eclampsia and its adverse outcomes in low- and middle income countries: a WHO secondary analysis. PLoS One 9, e91198.

[56] Candelotti, E., De Vito, P., Ahmed, R.G., Luly, P., Davis, P.J., Pedersen, J.Z., Lin, H-Y., Incerpi, I., 2015. Thyroid hormones crosstalk with growth factors: Old facts and new hypotheses. Immun., Endoc.\&Metab. Agents in Med. Chem., 15, 71-85.

[57] Carter, A.M., 2012. Evolution of placental function in mammals: the molecular basis of gas and nutrient transfer, hormone secretion, and immune responses. Physiol Rev 92, 15431576.

[58] Cartwright, J.E., Fraser, R., Leslie, K., Wallace, A.E., James, J.L., 2010. Remodelling at the maternal-fetal interface: relevance to human pregnancy disorders. Reproduction 140, 803813.

[59] De Vito, P., Candelotti, E., Ahmed, R.G., Luly, P., Davis, P.J., Incerpi, S., Pedersen, J.Z., 2015.Role of thyroid hormones in insulin resistance and diabetes. Immun., Endoc.\&Metab. Agents in Med. Chem., 15, 8693.

[60] El-bakry, A.M., El-Ghareeb, A.W.,Ahmed, R.G., 2010.Comparative study of the effects of experimentally-induced hypothyroidism and hyperthyroidism in some brain regions in albino rats.Int. J. Dev. Neurosci. 28, 371-389.

[61] El-Ghareeb, A.A., El-Bakry, A.M., Ahmed, R.G., Gaber, A., 2016.Effects of zinc supplementation in neonatal hypothyroidism and cerebellar distortion induced by maternal carbimazole. Asian Journal of Applied Sciences 4(04), 1030-1040.

[62] Fowden, A.L., Forhead, A.J., Sferruzzi-Perri, A.N., Burton, G.J., Vaughan, O.R., 2015. Review: endocrine regulation of placental phenotype. Placenta 36, S50-S59.

[63] Guttmacher, A.E., Maddox, Y.T., Spong, C.Y., 2014. The Human Placenta Project: placental structure, development, and function in real time. Placenta 35, 303-304.

[64] Haddow, J.E., Craig, W.Y., Neveux, L.M., Haddow, H.R., Palomaki, G.E., LambertMesserlian, G., Malone, F.D., D’Alton, M.E., 2014. First, Second Trimester Risk of
Aneuploidy Research C. Implications of high free thyroxine (FT4) concentrations in euthyroid pregnancies: the FaSTER trial. J ClinEndocrinolMetab. 99, 2038-2044.

[65] Incerpi, S., Hsieh, M-T., Lin, H-Y., Cheng, GY., De Vito, P., Fiore, A.M., Ahmed, R.G., Salvia, R., Candelotti, E., Leone, S., Luly, P., Pedersen, J.Z., Davis, F.B., Davis, P.J., 2014. Thyroid hormone inhibition in L6 myoblasts of IGF-I-mediated glucose uptake and proliferation: new roles for integrin $\alpha v \beta 3$. Am. J. Physiol. Cell Physiol. 307, C150-C161.

[66] Korevaar, T.I., Schalekamp-Timmermans, S., de Rijke, Y.B., Visser, W.E., Visser, W., de Muinck Keizer-Schrama, S.M., Hofman, A., Ross, H.A., Hooijkaas, H., Tiemeier, H., 2013. Hypothyroxinemia and TPO-antibody positivity are risk factors for premature delivery: the generation R study. J ClinEndocrinolMetab. 98, 4382-4390.

[67] Kovo, M., Schreiber, L., Ben-Haroush, A., Asalee, L., Seadia, S., Golan, A., Bar, J., 2011. The placental factor in spontaneous preterm labor with and without premature rupture of membranes. J Perinat Med. 39, 423-429.

[68] Krassas, G.E., Poppe, K., Glinoer, D., 2010. Thyroid function and human reproductive health.Endocr Rev. 31, 702-755.

[69] Loubiere, L.S., Vasilopoulou, E., Bulmer, J.N., Taylor, P.M., Stieger, B., Verrey, F., McCabe, C.J., Franklyn, J.A., Kilby, M.D., Chan, S.Y., 2010. Expression of thyroid hormone transporters in the human placenta and changes associated with intrauterine growth restriction. Placenta 31, 295-304.

[70] Matsuo, H., Maruo, T., Murata, K., Mochizuki, M., 1993. Human early placental trophoblasts produce an epidermal growth factor-like substance in synergy with thyroid hormone. ActaEndocrinol (Copenh) 128, 225-229.

[71] Medici, M., Korevaar, T.I., SchalekampTimmermans, S., Gaillard, R., de Rijke, Y.B., Visser, W.E., Visser, W., de Muinck KeizerSchrama, S.M., Hofman, A., Hooijkaas, H., 2014. Maternal early-pregnancy thyroid function is associated with subsequent hypertensive disorders of pregnancy: the generation R study. J ClinEndocrinolMetab.99, E2591-E2598.

[72] Medici, M., Timmermans, S., Visser, W., de Muinck Keizer-Schrama, S.M., Jaddoe, V.W., Hofman, A., Hooijkaas, H., de Rijke, Y.B., Tiemeier, H., Bongers-Schokking, J.J., 2013. Maternal thyroid hormone parameters during early pregnancy and birth weight: the generation R study. J ClinEndocrinolMetab. 98, 59-66.

[73] Odibo, A.O., Patel, K.R., Spitalnik, A., Odibo, L., Huettner, P., 2014. Placental pathology, 
first-trimester biomarkers and adverse pregnancy outcomes.J Perinatol. 34, 186-191.

[74] Oki, N., Matsuo, H., Nakago, S., Murakoshi, H., Laoag-Fernandez, J.B., Maruo, T., 2004. Effects of 3,5,3'-triiodothyronine on the invasive potential and the expression of integrins and matrix metalloproteinases in cultured early placental extravillous trophoblasts. J ClinEndocrinolMetab. 89, 52135221.

[75] Patel, J., Landers, K., Li, H., Mortimer, R.H., Richard, K., 2011. Oxygen concentration regulates expression and uptake of transthyretin, a thyroxine binding protein, in JEG-3 choriocarcinoma cells. Placenta 32, 128133.

[76] Sheehan, P.M., Nankervis, A., Araujo Junior, E., Da Silva Costa, F., 2015. Maternal thyroid disease and preterm birth: systematic review and meta-analysis. J ClinEndocrinolMetab 100, 4325-4331.
[77] Van Herck, S.L.J., Geysens, S., Bald, E., Chwatko, G., Delezie, E., Dianati, E., Ahmed, R.G., Darras, V.M., 2013.Maternal transfer of methimazole and effects on thyroid hormone availability in embryonic tissues.Endocrinol. 218, 105-115.

[78] Vasilopoulou, E., Loubiere, L.S., Lash, G.E., Ohizua, O., McCabe, C.J., Franklyn, J.A., Kilby, M.D., Chan, S.Y., 2014. Triiodothyronine regulates angiogenic growth factor and cytokine secretion by isolated human decidual cells in a cell-type specific and gestational age-dependent manner. Hum Reprod. 29, 1161-1172.

[79] Vinnars, M.T., Papadogiannakis, N., Nasiell, J., Holmstrom, G., Westgren, M., 2015. Placental pathology in relation to stillbirth and neonatal outcome in an extremely preterm population: a prospective cohort study. ActaObstetGynecolSc and 94, 584-590.

Citation: Ahmed R.G. Maternal Thyroid Function and Placental Hemodynamics. ARC Journal of Animal and Veterinary Sciences. 2018; 4(1):9-13. doi: dx.doi.org/ 10.20431/2455-2518.0401002.

Copyright: (C) 2018 Authors. This is an open-access article distributed under the terms of the Creative Commons Attribution License, which permits unrestricted use, distribution, and reproduction in any medium, provided the original author and source are credited. 